\title{
Pulmonary vascular development in congenital diaphragmatic hernia
}

\author{
Daphne S. Mous ${ }^{1}$, Heleen M. Kool ${ }^{1}$, Rene Wijnen ${ }^{1}$, Dick Tibboel ${ }^{1}$ and \\ Robbert J. Rottier ${ }^{1,2}$
}

Affiliations: ${ }^{1}$ Dept of Pediatric Surgery, Erasmus Medical Center-Sophia Children's Hospital, Rotterdam, The Netherlands. ${ }^{2}$ Dept of Cell Biology, Erasmus Medical Center, Rotterdam, The Netherlands.

Correspondence: Robbert J. Rottier, Dept Pediatric Surgery, Erasmus MC-Sophia Children's Hospital, PO Box 2040, 3000 CA Rotterdam, the Netherlands. E-mail: r.rottierderasmusmc.nl

@ERSpublications

Congenital pulmonary vascular diseases originate early during development, leading to clinical challenges http://ow.ly/EFno30hBhbv

Cite this article as: Mous DS, Kool HM, Wijnen R, et al. Pulmonary vascular development in congenital diaphragmatic hernia. Eur Respir Rev 2018; 27: 170104 [https://doi.org/10.1183/16000617.0104-2017].

ABSTRACT Congenital diaphragmatic hernia $(\mathrm{CDH})$ is a rare congenital anomaly characterised by a diaphragmatic defect, persistent pulmonary hypertension $(\mathrm{PH})$ and lung hypoplasia. The relative contribution of these three elements can vary considerably in individual patients. Most affected children suffer primarily from the associated $\mathrm{PH}$, for which the therapeutic modalities are limited and frequently not evidence based. The vascular defects associated with $\mathrm{PH}$, which is characterised by increased muscularisation of arterioles and capillaries, start to develop early in gestation. Pulmonary vascular development is integrated with the development of the airway epithelium. Although our knowledge is still incomplete, the processes involved in the growth and expansion of the vasculature are beginning to be unravelled. It is clear that early disturbances of this process lead to major pulmonary growth abnormalities, resulting in serious clinical challenges and in many cases death in the newborn. Here we provide an overview of the current molecular pathways involved in pulmonary vascular development. Moreover, we describe the abnormalities associated with $\mathrm{CDH}$ and the potential therapeutic approaches for this severe abnormality.

\section{Normal pulmonary vascular development}

Human lung development can be divided into different stages based on histology, starting with the embryonic stage at 4 weeks of gestation, followed by the pseudoglandular stage in which branching of the lung buds continues. During the canalicular stage, starting at $\sim 16$ weeks of gestation, the terminal bronchioli are formed. From 24 weeks of gestation until term, the saccular stage, airspaces widen and alveoli are formed. During the alveolar stage, which persists into the postnatal period up to 3 years of age, maturation of the airways occurs [1]. Concomitant with the expansion of the airways is the adaptation of the microvasculature to optimise the exchange of oxygen and carbon dioxide between the blood and the airways. We and others have shown that very early in lung development pulmonary vessels are present and connected to the systemic circulation. The vasculature develops in close relation with the airways and is a rate-limiting factor in branching morphogenesis [2-4]. This implies that the pulmonary vasculature plays an important role in lung development. The formation of new blood vessels primarily occurs through

Received: Sept 072017 | Accepted after revision: Nov 092017

Support statement: This work was supported in part by the Sophia Foundation for Medical Research grant number 678 (awarded to H.M. Kool). Funding information for this article has been deposited with the Crossref Funder Registry.

Conflict of interest: None declared.

Provenance: Commissioned article, peer reviewed.

Copyright CERS 2018. ERR articles are open access and distributed under the terms of the Creative Commons Attribution Non-Commercial Licence 4.0. 
sprouting of new capillaries from pre-existing vessels at the growing tips of the branching epithelium, a process referred to as distal angiogenesis [4]. The newly formed endothelial tubes need to be stabilised by perivascular cells, pericytes, to become functional capillaries in a platelet derived growth factor- $\beta$ dependent manner $[5,6]$. Little is known about the pericyte population during lung development, but pericytes have been shown to originate from $\mathrm{Wnt} 2^{+} / \mathrm{Glil}^{+} / \mathrm{Isl} 1^{+}$multipotent cardiopulmonary mesoderm progenitors [7].

Pulmonary vascular resistance is high during gestation and decreases rapidly after birth under the influence of breathing movements, gas exchange and the release of vasoactive factors of the endothelin $(\mathrm{ET})$, nitric oxide $(\mathrm{NO})$ and prostacyclin $\left(\mathrm{PGI}_{2}\right)$ pathways $[8,9]$ (figure 1 ). The ET pathway is activated by three ligands: ET-1, ET-2 and ET-3, of which ET-1 is the most common isoform [10, 11]. The ET-1 precursor protein, prepro-ET-1, is cleaved by furin into big-ET-1, which is subsequently processed to its active form by the endothelin-converting enzyme-1 and binds and activates two different G-protein coupled receptors, ETA and ETB, with equal affinity. The ETA receptor is located at the cell surface of vascular smooth muscle cells and induces vasoconstriction and cell proliferation by activating phospholipase C, whereas the ETB receptor is located mainly in the cell membrane of the endothelium and induces vasodilation by regulating the release of $\mathrm{NO}$ and $\mathrm{PGI}_{2}[11,12]$. Furthermore, ET-1 promotes cell growth, cell adhesion and thrombosis and is increased in lung tissue of patients with pulmonary hypertension $(\mathrm{PH})$. A negative feedback loop is triggered by NO that reduces the affinity of the ETA receptor for ET-1 and can therefore prevent ET-1-mediated signalling [12]. NO can be synthesised by one of three different NO synthases (NOS), of which endothelial (e)NOS is the most important synthase involved in the regulation of the pulmonary vascular tone and is highly expressed in the endothelial cells [13]. NO can bind to its receptor, soluble guanylyl cyclase, which can synthesise the second messenger cyclic guanosine monophosphate, thereby inducing vasodilation. The third important pathway involves prostaglandins and thromboxanes that act on prostanoid receptors which can be divided in receptors that cause relaxation (IP (PTGIR), EP2, EP4 and DP) or contraction (TP, EP1 and FP) of the pulmonary vessels to change the vascular tone [14]. $\mathrm{PGI}_{2}$ is an important mediator of vasodilation which binds and activates the prostaglandin- $\mathrm{I}_{2}$ receptor (PTGIR) $[15,16]$. This activation results in vasodilation through the release of cAMP. Apart from these vasoactive factors, retinoic acid signalling has been shown to be important in lung development [17]. Retinoic acid is formed from vitamin A through several sequential enzymatic reactions. Subsequently, it binds to one of the retinoic acid receptors (RAR/RXR) which subsequently modulate transcription of target genes through retinoic acid responsive element [18]. Pharmacological or genetic inactivation of retinoic acid signalling in the early foregut resulted in an increased expression of the Wingless-type MMTV integration site family (Wnt) antagonist Dickkopf (Dkk1) and transforming growth factor (TGF)- $\beta$, which plays an important role in airway branching and muscularisation of the pulmonary vasculature [19]. Thus, retinoic acid integrates two important regulatory signalling pathways, Wnt and TGF- $\beta$, in the control of Fgf10 expression.

Alveolar formation starts late in development and continues into the first years of life to expand the gas exchanging capacity of the lung. TGF- $\beta$ partly regulates the concomitant adaptation of the microvasculature. There are two main branches in the TGF- $\beta$ superfamily: the TGF- $\beta$ /activin family and the bone morphogenetic protein (BMP) family. All proteins of the TGF- $\beta$ superfamily act through two classes of serine/threonine kinase receptors: type 1 and type 2 . Active TGF- $\beta$ or BMP can be bound to a specific type 2 receptor, which phosphorylates and activates a type 1 receptor. The activated type 1 receptor subsequently phosphorylates a set of receptor-regulated small body size/mothers against decapentaplegic proteins (Smads), which form a complex with co-Smad (Smad4). TGF- $\beta$ is responsible for the phosphorylation of Smad2 and Smad 3, whereas BMP phosphorylates Smad 1, 5 and 8. Eventually, the $\mathrm{R}-\mathrm{Smad} / \mathrm{co}-\mathrm{Smad}$ complex modulates the transcription of target genes in the nucleus [20] (figure 2). TGF- $\beta$ signalling is necessary in vascular and airway smooth muscle cells, and in alveolar and airway epithelial cells during late lung development [21]. Previous studies in rodents showed an arrest in alveolarisation both in animals with upregulated TGF- $\beta$ signalling [22] and after a complete blockade of TGF- $\beta$ signalling [23], indicating the important differences in TGF- $\beta$ signalling between early and late lung development.

\section{Pulmonary vascular development in congenital diaphragmatic hernia}

Congenital diaphragmatic hernia $(\mathrm{CDH})$ is a rare congenital anomaly characterised by a diaphragmatic defect, PH and lung hypoplasia. It has a worldwide incidence of $\sim 1$ in 3000 live births [24, 25] and mortality varies from $20 \%$ to $40 \%$ [26]. The high mortality and morbidity rates may depend on the presence of associated malformations and/or genetic abnormalities, but are mostly due to the concomitant $\mathrm{PH}$. $\mathrm{PH}$ is the result of the altered development of the pulmonary vasculature, the unpredictable vascular reactivity and the disordered process of pulmonary vascular remodelling [27, 28]. PH associated with $\mathrm{CDH}$ is characterised by extensive muscularisation of the vessels, which is noticeable early in gestation 


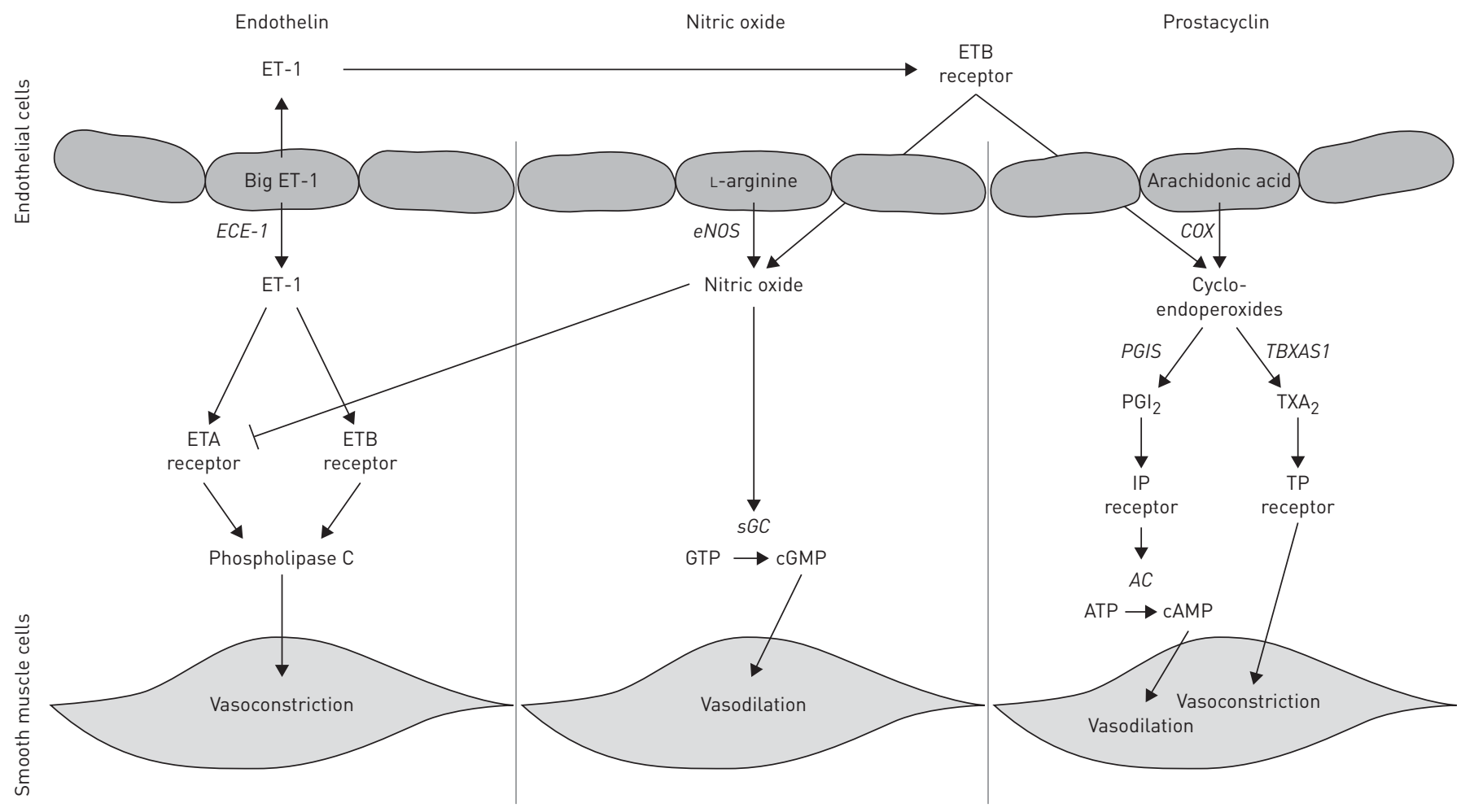

FIGURE 1 Overview of the major pathways involved in vasodilation and vasoconstriction. ET: endothelin; ECE: endothelin-converting enzyme; ETA: endothelin $A$; ETB: endothelin $B$; eNOS: endothelial nitric oxide synthase; sGC: soluble guanylate cyclase; COX: cyclooxygenase; PGIS: prostaglandin synthase; $\mathrm{PGI}_{2}$ : prostaglandin $\mathrm{I}_{2}$; $\mathrm{AC}$ : adenylate cyclase; TBXAS1: thromboxane synthase; $\mathrm{TXA}_{2}$ : thromboxane.

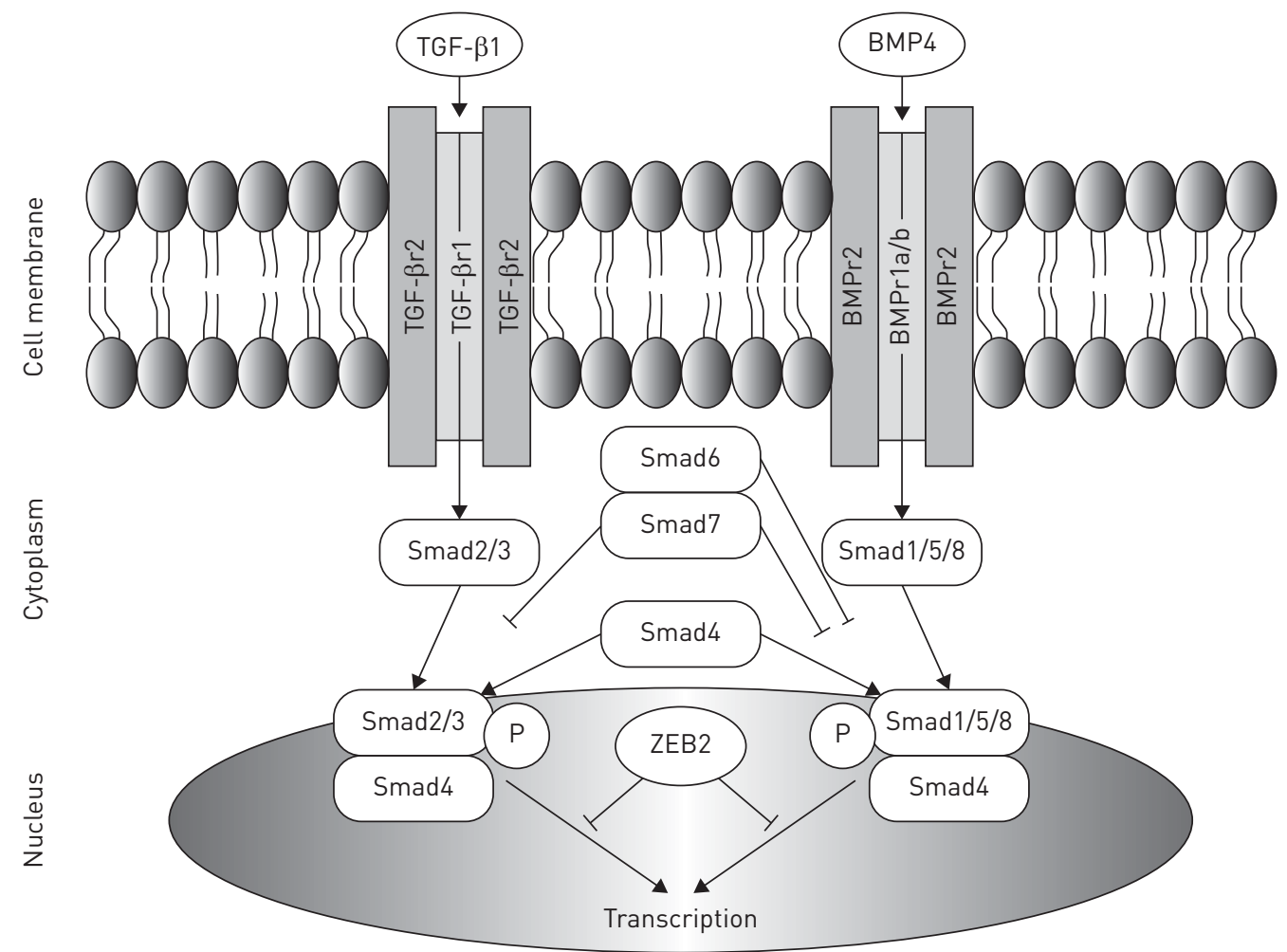

FIGURE 2 Overview of transforming growth factor (TGF)- $\beta$ /bone morphogenetic protein (BMP) pathway. ZEB2: zinc finger E-box binding homeobox 2; P: phosphorylation; Smad: small body size/mothers against decapentaplegic proteins 
[29]. This indicates that the structural abnormalities start to develop when the lung is very immature. The pathology of $\mathrm{PH}$ is characterised by hypermuscularisation of the midsized and large vessels and neomuscularisation of the small capillaries $[18,28,30,31]$. Pericytes are prime candidates to underlie and eventually modulate the structural changes observed in $\mathrm{PH}$ associated with $\mathrm{CDH}[6,32]$. Differences in pericyte coverage have been linked to other diseases with a prominent vascular component, such as diabetic retinopathy, cancer and adult pulmonary arterial hypertension [33-35]. Additionally, co-cultured pulmonary arterial endothelial cells and smooth muscle cells showed an altered interaction when cells were used from a $\mathrm{CDH}$ sheep model [36].

Aberrations in the expression of different factors in the important vasoactive pathways have previously been described by us and others. Increased levels of both the ETA and ETB receptors were shown in human $\mathrm{CDH}$ [37] and high plasma levels of circulating ET-1 were associated with the severity of $\mathrm{PH}$ in this population [38]. Studies on the expression of eNOS showed variable results, where a decrease was found in some human studies [39], but no differences or even an increased expression of eNOS was shown by us and others [40]. No studies have been performed on the expression of factors of the $\mathrm{PGI}_{2}$ pathway.

Finally, recent studies implicated microRNAs in the development of $\mathrm{CDH}$, but it remains to be seen whether the changes observed in miR-200b and miR-10a are a cause or a consequence of CDH $[41,42]$.

\section{Treatment of pulmonary vascular defects in CDH}

The significance of $\mathrm{PH}$ in the mortality and morbidity of patients with $\mathrm{CDH}$ has been increasingly recognised. Extracorporeal membrane oxygenation may be provided as a treatment of last resort to relieve the respiratory distress of these children and provide time for the pulmonary vasculature to adjust to the postnatal increased flow to the pulmonary vascular bed. However, the persistent $\mathrm{PH}$ requires more targeted approaches to improve the oxygenation of these children. The first vasodilators used in these critically ill newborns with $\mathrm{PH}$, tolazoline [43], an $\alpha$-adrenergic receptor antagonist, and prostacyclin [44], a $\mathrm{PGI}_{2}$ agonist, resulted in variable results. Tolazoline infusion showed a response in 21 out of 36 neonatal patients with lung disease, where systemic hypotension and bleeding tendency were seen as a severe side-effect in several patients [43]. Treatment with $\mathrm{PGI}_{2}$ improved pulmonary arterial pressure and oxygenation in two out of three neonatal patients with idiopathic $\mathrm{PH}$ and $\mathrm{PH}$ caused by meconium aspiration. However, it had no beneficial effect in two patients with $\mathrm{CDH}$, whereas systemic hypotension was seen as a side-effect in one of these patients [44]. Currently, patients with CDH still respond unpredictably to the available vasodilator therapy due to the lack of understanding of the underlying mechanisms in the individual patient. Inhaled (i)NO is most commonly used, but studies have failed to show its efficacy in this specific group of patients [45]. Apart from iNO, sildenafil and some prostaglandin analogues are used as rescue therapy in a compassionate way in the most severe cases, but with variable results [46-48]. No appropriate trials have been performed on these drugs and, with a few exceptions, no data on pharmacokinetics are available for $\mathrm{CDH}$ neonates. In the near future a comparative effectiveness trial will be conducted to compare iNO with i.v. sildenafil under the guidance of the CDH-EURO Consortium.

Currently, the only prenatal intervention used in $\mathrm{CDH}$ undergoing clinical trial is fetoscopic endoluminal tracheal occlusion (FETO), where a small balloon is inserted into the fetal trachea to temporarily block the airway for a period of 4-6 weeks (Tracheal Occlusion to Accelerate Lung Growth (TOTAL); clinicaltrials.gov NCT02875860) [49]. As a result, fluid is trapped in the lungs, creating internal pressure which forces the lung to grow. This idea of blocking the airway emerged from an experiment of nature in patients with congenital high airway obstruction syndrome resulting in big polyalveolar lungs [50]. Previous research has shown that tracheal occlusion can indeed cause an increase in lung growth $[51,52]$ and removing the balloon before birth has shown to be necessary for a better maturation of the lung by decreasing the apoptosis of the alveolar type 2 cells, which produce surfactant, an essential compound for lung function [53]. So far, FETO has been shown to improve survival rate in high-risk CDH patients, but at the cost of increased morbidity and premature delivery [54-56]. The results of the TOTAL trial will hopefully provide a more definitive answer.

Currently, treatment with vasodilators in patients with $\mathrm{CDH}$ is only used postnatally, where previous research has shown already major differences in the pulmonary vasculature early in development [29]. We and others have performed some studies on the antenatal use of the phosphodiesterase-5 inhibitor sildenafil in different animal models of $\mathrm{CDH}$, showing improvement in alveolarisation and pulmonary vascular development [57-61]. However, the pulmonary pathology in these treated animals did not show complete reversal to the normal lung histology. 
The absence of an integrated analysis of the hypermuscularisation, pericyte coverage and the pathways regulating vascular tone, as well as the ineffective postnatal treatment in individual patients with $\mathrm{CDH}$ makes it essential to obtain greater insight into the aberrant development of the pulmonary vasculature to optimise treatment in these patients. Furthermore, adequate prenatal treatment could be beneficial for pulmonary development and its vascular pathology, in particular in newborns with $\mathrm{CDH}$.

\section{References}

1 Warburton D, El-Hashash A, Carraro G, et al. Lung organogenesis. Curr Top Dev Biol 2010; 90: 73-158.

2 Schwarz MA, Zhang F, Lane JE, et al. Angiogenesis and morphogenesis of murine fetal distal lung in an allograft model. Am J Physiol Lung Cell Mol Physiol 2000; 278: L1000-L1007.

3 van Tuyl M, Liu J, Wang J, et al. Role of oxygen and vascular development in epithelial branching morphogenesis of the developing mouse lung. Am J Physiol Lung Cell Mol Physiol 2005; 288: L167-L178.

4 Parera MC, van Dooren M, van Kempen M, et al. Distal angiogenesis: a new concept for lung vascular morphogenesis. Am J Physiol Lung Cell Mol Physiol 2005; 288: L141-L149.

5 Hellström M, Kalén M, Lindahl P, et al. Role of PDGF-B and PDGFR- $\beta$ in recruitment of vascular smooth muscle cells and pericytes during embryonic blood vessel formation in the mouse. Development 1999; 126: 3047-3055.

6 Armulik A, Abramsson A, Betsholtz C. Endothelial/pericyte interactions. Circ Res 2005; 97: 512-523.

7 Peng T, Tian Y, Boogerd CJ, et al. Coordination of heart and lung co-development by a multipotent cardiopulmonary progenitor. Nature 2013; 500: 589-592.

8 Lévy M, Maurey C, Dinh-Xuan AT, et al. Developmental expression of vasoactive and growth factors in human lung. Role in pulmonary vascular resistance adaptation at birth. Pediatr Res 2005; 57: 21R-25R.

9 Hillman NH, Kallapur SG, Jobe AH. Physiology of transition from intrauterine to extrauterine life. Clin Perinatol 2012; 39: 769-783.

10 Inoue A, Yanagisawa M, Kimura S, et al. The human endothelin family: three structurally and pharmacologically distinct isopeptides predicted by three separate genes. Proc Natl Acad Sci USA 1989; 86: 2863-2867.

11 Davenport AP, Hyndman KA, Dhaun N, et al. Endothelin. Pharmacol Rev 2016; 68: 357-418.

12 Michael JR, Markewitz BA. Endothelins and the lung. Am J Respir Crit Care Med 1996; 154: 555-581.

13 Francis SH, Busch JL, Corbin JD, et al. cGMP-dependent protein kinases and cGMP phosphodiesterases in nitric oxide and cGMP action. Pharmacol Rev 2010; 62: 525-563.

14 Mubarak KK. A review of prostaglandin analogs in the management of patients with pulmonary arterial hypertension. Respir Med 2010; 104: 9-21.

15 Weinberger B, Weiss K, Heck DE, et al. Pharmacologic therapy of persistent pulmonary hypertension of the newborn. Pharmacol Ther 2001; 89: 67-79.

16 Gao Y, Raj JU. Regulation of the pulmonary circulation in the fetus and newborn. Physiol Rev 2010; 90: 1291-1335.

17 Malpel S, Mendelsohn C, Cardoso WV. Regulation of retinoic acid signaling during lung morphogenesis. Development 2000; 127: 3057-3067.

18 Kool $\mathrm{H}$, Mous $\mathrm{D}$, Tibboel $\mathrm{D}$, et al. Pulmonary vascular development goes awry in congenital lung abnormalities. Birth Defects Res C Embryo Today 2014; 102: 343-358.

19 Chen F, Desai TJ, Qian J, et al. Inhibition of Tgf $\beta$ signaling by endogenous retinoic acid is essential for primary lung bud induction. Development 2007; 134: 2969-2979.

20 Weiss A, Attisano L. The TGFbeta superfamily signaling pathway. Wiley Interdiscip Rev Dev Biol 2013; 2: 47-63.

21 Alejandre-Alcázar MA, Michiels-Corsten M, Vicencio AG, et al. TGF- $\beta$ signaling is dynamically regulated during the alveolarization of rodent and human lungs. Dev Dyn 2008; 237: 259-269.

22 Alejandre-Alcázar MA, Kwapiszewska G, Reiss I, et al. Hyperoxia modulates TGF- $\beta / B M P$ signaling in a mouse model of bronchopulmonary dysplasia. Am J Physiol Lung Cell Mol Physiol 2007; 292: L537-L549.

23 Chen H, Sun J, Buckley S, et al. Abnormal mouse lung alveolarization caused by Smad3 deficiency is a developmental antecedent of centrilobular emphysema. Am J Physiol Lung Cell Mol Physiol 2005; 288: L683-L691.

24 Torfs CP, Curry CJ, Bateson TF, et al. A population-based study of congenital diaphragmatic hernia. Teratology 1992; 46: 555-565.

25 McGivern MR, Best KE, Rankin J, et al. Epidemiology of congenital diaphragmatic hernia in Europe: a register-based study. Arch Dis Child Fetal Neonatal Ed 2015; 100: F137-F144.

26 Lally KP. Congenital diaphragmatic hernia - the past 25 (or so) years. J Pediatr Surg 2016; 51: 695-698.

27 Miniati D. Pulmonary vascular remodeling. Semin Pediatr Surg 2007; 16: 80-87.

28 Sluiter I, Reiss I, Kraemer U, et al. Vascular abnormalities in human newborns with pulmonary hypertension. Expert Rev Respir Med 2011; 5: 245-256.

29 Sluiter I, van der Horst I, van der Voorn P, et al. Premature differentiation of vascular smooth muscle cells in human congenital diaphragmatic hernia. Exp Mol Pathol 2013; 94: 195-202.

30 Rottier R, Tibboel D. Fetal lung and diaphragm development in congenital diaphragmatic hernia. Semin Perinatol 2005; 29: 86-93.

31 Sluiter I, Veenma D, van Loenhout R, et al. Etiological and pathogenic factors in congenital diaphragmatic hernia. Eur J Pediatr Surg 2012; 22: 345-354.

32 Armulik A, Genové G, Betsholtz C. Pericytes: developmental, physiological, and pathological perspectives, problems, and promises. Dev Cell 2011; 21: 193-215.

33 Hammes HP, Lin J, Renner O, et al. Pericytes and the pathogenesis of diabetic retinopathy. Diabetes 2002; 51: 3107-3112.

34 Bergers G, Song S. The role of pericytes in blood-vessel formation and maintenance. Neuro Oncol 2005; 7: 452-464.

35 Ricard N, Tu L, Le Hiress M, et al. Increased pericyte coverage mediated by endothelial-derived fibroblast growth factor- 2 and interleukin-6 is a source of smooth muscle-like cells in pulmonary hypertension. Circulation 2014; 129: $1586-1597$.

36 Acker SN, Seedorf GJ, Abman SH, et al. Altered pulmonary artery endothelial-smooth muscle cell interactions in experimental congenital diaphragmatic hernia. Pediatr Res 2015; 77: 511-519. 
37 de Lagausie P, de Buys-Roessingh A, Ferkdadji L, et al. Endothelin receptor expression in human lungs of newborns with congenital diaphragmatic hernia. J Pathol 2005; 205: 112-118.

38 Keller RL, Tacy TA, Hendricks-Munoz K, et al. Congenital diaphragmatic hernia: endothelin-1, pulmonary hypertension, and disease severity. Am J Respir Crit Care Med 2010; 182: 555-561.

39 North AJ, Moya FR, Mysore MR, et al. Pulmonary endothelial nitric oxide synthase gene expression is decreased in a rat model of congenital diaphragmatic hernia. Am J Respir Cell Mol Biol 1995; 13: 676-682.

40 Shehata SM, Sharma HS, Mooi WJ, et al. Pulmonary hypertension in human newborns with congenital diaphragmatic hernia is associated with decreased vascular expression of nitric-oxide synthase. Cell Biochem Biophys 2006; 44: 147-155.

41 Mahood TH, Johar DR, Iwasiow BM, et al. The transcriptome of nitrofen-induced pulmonary hypoplasia in the rat model of congenital diaphragmatic hernia. Pediatr Res 2016; 79: 766-775.

42 Pereira-Terra P, Deprest JA, Kholdebarin R, et al. Unique tracheal fluid microRNA signature predicts response to FETO in patients with congenital diaphragmatic hernia. Ann Surg 2015; 262: 1130-1140.

43 Goetzman BW, Sunshine P, Johnson JD, et al. Neonatal hypoxia and pulmonary vasospasm: response to tolazoline. J Pediatr 1976; 89: 617-621.

44 Kääpä $\mathrm{P}$, Koivisto $\mathrm{M}$, Ylikorkala $\mathrm{O}$, et al. Prostacyclin in the treatment of neonatal pulmonary hypertension. J Pediatr 1985; 107: 951-953.

45 Finer NN, Barrington KJ. Nitric oxide for respiratory failure in infants born at or near term. Cochrane Database Syst Rev 2006; 4: CD000399.

46 Olson E, Lusk LA, Fineman JR, et al. Short-term treprostinil use in infants with congenital diaphragmatic hernia following repair. J Pediatr 2015; 167: 762-764.

47 Skarda DE, Yoder BA, Anstadt EE, et al. Epoprostenol does not affect mortality in neonates with congenital diaphragmatic hernia. Eur J Pediatr Surg 2015; 25: 454-459.

48 Bialkowski A, Moenkemeyer F, Patel N. Intravenous sildenafil in the management of pulmonary hypertension associated with congenital diaphragmatic hernia. Eur J Pediatr Surg 2015; 25: 171-176.

49 Deprest J, Brady P, Nicolaides K, et al. Prenatal management of the fetus with isolated congenital diaphragmatic hernia in the era of the TOTAL trial. Semin Fetal Neonatal Med 2014; 19: 338-348.

50 Gupta A, Yadav C, Dhruw S, et al. CHAOS. J Obstet Gynaecol India 2016; 66: 202-208.

51 Hedrick MH, Estes JM, Sullivan KM, et al. Plug the lung until it grows (PLUG): a new method to treat congenital diaphragmatic hernia in utero. J Pediatr Surg 1994; 29: 612-617.

52 Harrison MR, Mychaliska GB, Albanese CT, et al. Correction of congenital diaphragmatic hernia in utero IX: fetuses with poor prognosis (liver herniation and low lung-to-head ratio) can be saved by fetoscopic temporary tracheal occlusion. J Pediatr Surg 1998; 33: 1017-1022.

53 Flageole H, Evrard VA, Piedboeuf B, et al. The plug-unplug sequence: an important step to achieve type II pneumocyte maturation in the fetal lamb model. J Pediatr Surg 1998; 33: 299-303.

54 Shan W, Wu Y, Huang G, et al. Foetal endoscopic tracheal occlusion for severe congenital diaphragmatic hernia a systemic review and meta-analysis of randomized controlled trials. J Pak Med Assoc 2014; 64: 686-689.

55 Ali K, Bendapudi P, Polubothu S, et al. Congenital diaphragmatic hernia - influence of fetoscopic tracheal occlusion on outcomes and predictors of survival. Eur J Pediatr 2016; 175: 1071-1076.

56 Al-Maary J, Eastwood MP, Russo FM, et al. Fetal tracheal occlusion for severe pulmonary hypoplasia in isolated congenital diaphragmatic hernia: a systematic review and meta-analysis of survival. Ann Surg 2016; 264: 929-933.

57 Mous DS, Kool HM, Buscop-van Kempen MJ, et al. Clinically relevant timing of antenatal sildenafil treatment reduces pulmonary vascular remodeling in congenital diaphragmatic hernia. Am J Physiol Lung Cell Mol Physiol 2016; 311: L734-L742.

58 Luong C, Rey-Perra J, Vadivel A, et al. Antenatal sildenafil treatment attenuates pulmonary hypertension in experimental congenital diaphragmatic hernia. Circulation 2011; 123: 2120-2131.

59 Lemus-Varela Mde L, Soliz A, Gómez-Meda BC, et al. Antenatal use of bosentan and/or sildenafil attenuates pulmonary features in rats with congenital diaphragmatic hernia. World J Pediatr 2014; 10: 354-359.

60 Makanga M, Maruyama H, Dewachter C, et al. Prevention of pulmonary hypoplasia and pulmonary vascular remodeling by antenatal simvastatin treatment in nitrofen-induced congenital diaphragmatic hernia. Am J Physiol Lung Cell Mol Physiol 2015; 308: L672-L682.

61 Russo FM, Toelen J, Eastwood MP, et al. Transplacental sildenafil rescues lung abnormalities in the rabbit model of diaphragmatic hernia. Thorax 2016; 71: 517-525. 